\title{
MACROSEISMIC INVESTIGATIONS
} OF THE GEOLOGICAL SITE EFFECTS ON INTENSITIES OF SELECTED EARTHQUAKES IN THE GREATER LJUBLJANA AREA

MAKROSEIZMIČNE RAZISKAVE VPLIVOV LOKALNE GEOLOŠKE ZGRADBE NA INTENZITETE IZBRANIH POTRESOV NA ŠIRŠEM OBMOČJU LJUBLJANE

Anita Jerše, Andrej Gosar, Mladen Živčić

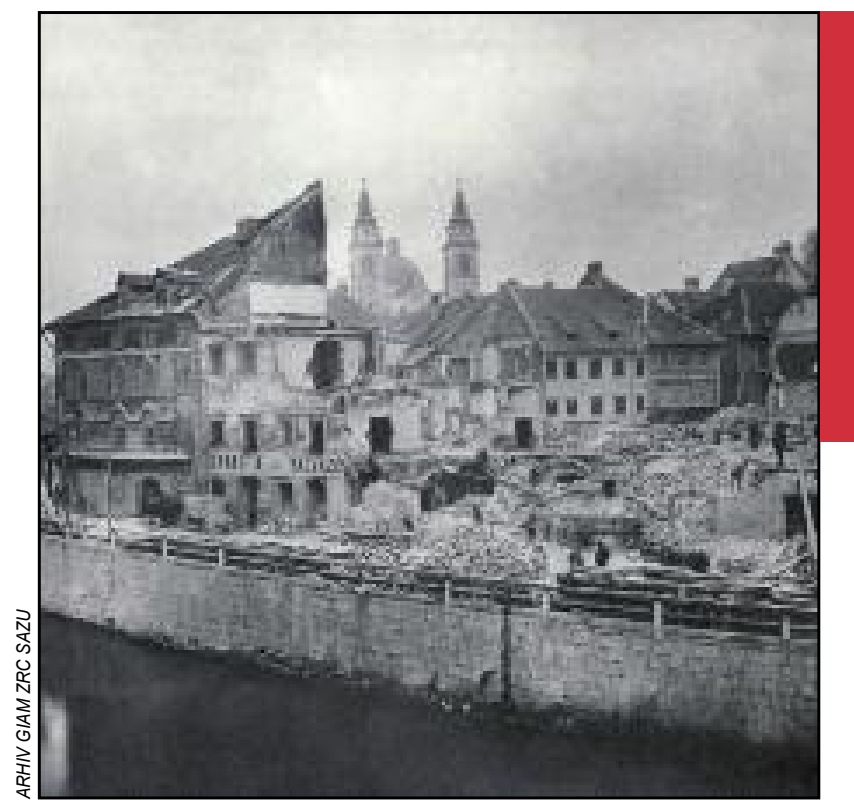

Consequences of the Ljubljana 1895 earthquake. Posledice potresa 1895 v Ljubljani. 


\title{
Macroseismic investigations of the geological site effects on intensities of selected earthquakes in greater Ljubljana area
}

\author{
DOI: http://dx.doi.org/10.3986/AGS.793 \\ UDC: 550.34(497.451) \\ COBISS: 1.01
}

\begin{abstract}
Ljubljana is one of three regions with the highest seismic hazard in Slovenia. In addition soft sediments in the Ljubljana basin have a strong influence on seismic ground motion. We used macroseismic data to investigate the influence of local geological structure on earthquake intensities in greater Ljubljana area. We determined intensities for eleven earthquakes according to ground classification based on Eurocode 8 standard (EC8). The results showed a systematic increase in observed seismic intensities, determined according to European Macroseismic Scale (EMS-98), as the seismogeological characteristics of the ground deteriorated. Only one ground type (D) showed slightly lower intensities than expected. This may be due to some unrevealed geological and other factors, or because of very limited macroseismic data available for this particular ground type.
\end{abstract}

KEY WORDS: European Macroseismic Scale, intensity, macroseismic investigations, Eurocode 8, seismic microzonation, Ljubljana basin

The article was submitted for publication on May $9^{\text {th }}, 2014$.

\section{ADDRESSES:}

Anita Jerše

Slovenian Environment Agency

Seismology and Geology Office

Dunajska 47, SI - 1000 Ljubljana, Slovenia

E-mail: anita.jerse@gmail.com

Mladen Živčić, M.Sc.

Slovenian Environment Agency

Seismology and Geology Office

Dunajska 47, SI - 1000 Ljubljana, Slovenia

E-mail: mladen.zivcic@gov.si

Andrej Gosar, Ph.D.

Slovenian Environment Agency

Seismology and Geology Office

Dunajska 47, SI - 1000 Ljubljana, Slovenia

and

University of Ljubljana

Faculty of Natural Sciences and Engineering

Aškerčeva 12, SI - 1000, Ljubljana, Slovenia

E-mail: andrej.gosar@gov.si 


\section{Introduction}

Earthquakes are a natural phenomenon that cannot be forecasted and controlled, but that can be well observed through the analysis of its effects. Macroseismic data consist of systematic descriptions of earthquakes' effects on humans, objects, buildings and nature.

The amplitude of ground oscillation depends on earthquakes' source properties (magnitude, depth, distance, focal mechanism), on the impact of regional geology on the propagation of seismic waves, and on the local geological condition known as site effects. In seismic hazard assessment for a site located on a soft ground the value of ground-motion acceleration on a base solid rock is multiplied by a corresponding soil factor.

The aim of this study is to evaluate the influence of local geological structure on certain earthquake intensities in the greater Ljubljana area, based on the ground classification according to Eurocode 8 standard (EC8) (SIST EN 1998-1, 2005; SIST EN 1998-1/A101, 2005). For the purposes of macroseismic analysis we evaluated macroseismic questionnaires, which are kept in our archive. In estimating intensity we followed the principles of the European Macroseismic Scale (EMS-98) (Grünthal 1998). Intensities were determined for areas with a radius not exceeding $5 \mathrm{~km}$, which were located on homogeneous ground in accordance to EC8 classification. Based on the geological map, in scale $1: 100,000$, and its map interpreters, we divided geological substrate areas into five classes according to EC8. Data of three separate groups of earthquakes was statistically analysed. For each group we have selected the reference intensity of the comparative polygon, with which we compared the intensity in other polygons for the same earthquake.

\section{Previous research of the influence of local geological structure on earthquake effects}

Seismic wave amplification in alluvial deposits has contributed to damage and loss of life in several recent earthquakes, for example in Christchurch, 2011 (Bradley 2012) and in Emilia-Romagna 2012 (Maugeri et al. 2013). In areas with complex geology site effects can vary significantly (Toshinawa et al. 1997). Many techniques all over the world have been presented to investigate the relationship between intensity and geological setting using macroseismic data. The first significant study of this kind was made in New Zealand (Elder et al. 1991; Toshinawa et al. 1997). Also in Italy there have been several studies on the variation of earthquakes effects caused by site effects, for example in Palermo (Giammarinaro et al. 2005) and Rome (Cifelli et al. 2000; Sbarra et al. 2012). In Slovenia large variations in damage to buildings were observed in case of 1998 and $2004 \mathrm{Krn}$ mountains earthquakes. They were explained mainly by soil-structure resonance effects (Gosar 2007; Gosar 2010).

Based on recent studies, experts had suggested (Sbarra et al. 2012) using macroseismic intensity residuals as a contribution to the elaboration of hazard maps. They found that the intensity also depends on soil variations with the depth and thickness of each layer.

\section{Geological setting and ground classification based on EC8 in the greater Ljubljana area}

Ljubljana, which is one of three regions with the highest seismic hazard in Slovenia (Lapajne et al. 2001), is located in a shallow sedimentary basin filled with heterogeneous Quaternary deposits (Figure 1) with various seismological properties. We distinguish three main parts: the Ljubljana Field (Ljubljansko polje), the north part of the Ljubljana Moor (Ljubljansko barje), and surrounding hills.

The bedrock of the basin is built of Permian and Carboniferous clastic rocks (claystones, sandstones, conglomerates) and partly of Mesozoic carbonate rocks. It outcrops on the margins of the hills. Ljubljana Field is covered by gravel deposits of the Sava River. Sand and gravel in the Ljubljana Moor are covered by lake and marsh sediments.

In EC8 site effects of different ground types are expressed with coefficient $S$ (soil factor), which tell us how much greater the ground acceleration is expected in comparison with the reference solid rock. There 


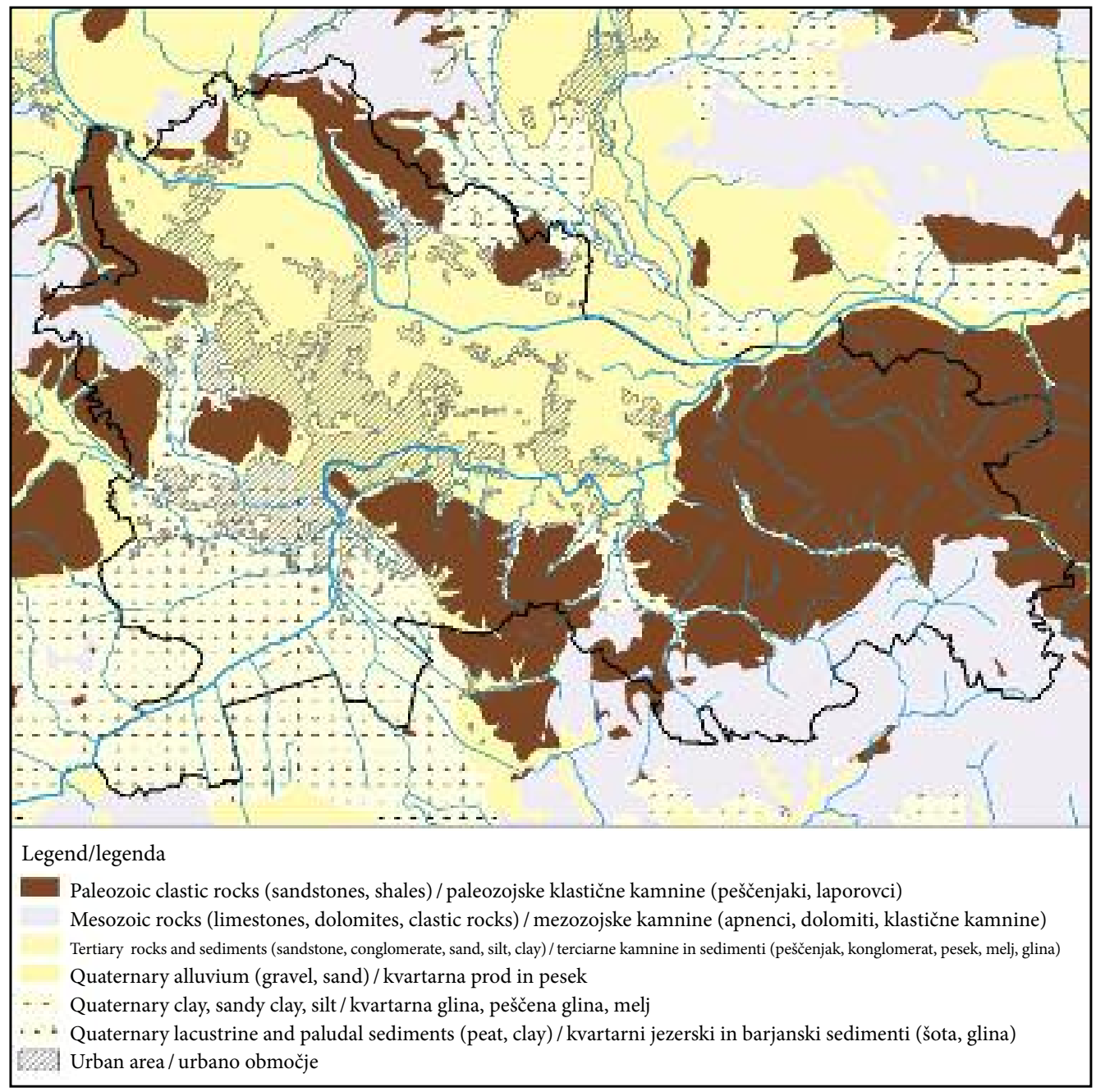

Figure 1: Geological map of the Ljubljana region (Zupančič et al. 2004).

are seven ground types described by the stratigraphic profiles and by three quantitative parameters: average shear-wave velocity in the topmost $30 \mathrm{~m}$ of sediments $\left(v_{\mathrm{s}, 30}\right)$, the result of Standard Penetration Test $\left(\mathrm{N}_{\text {spt }}\right)$ and the undrained shear strength $\left(c_{u}\right)$. For special ground types $S_{1}$ and $S_{2}$, soil factor $S$ is not given and must be determined by specific investigations.

The influence of local geological structure on seismic ground motion is given in a microzonation map. Based on the geological map (OGK 100) and the map interpreter we expanded the seismic microzonation map of the Municipality of Ljubljana (Zupančič et al. 2004) to greater Ljubljana area (Figure 2). The ground is classified into five types:

- A - factor 1.00 ,

- C - factor 1.15,

- D - factor 1.35 ,

- E - factor 1.70,

- $\mathrm{S}_{1}$ - factor 2.55 . 


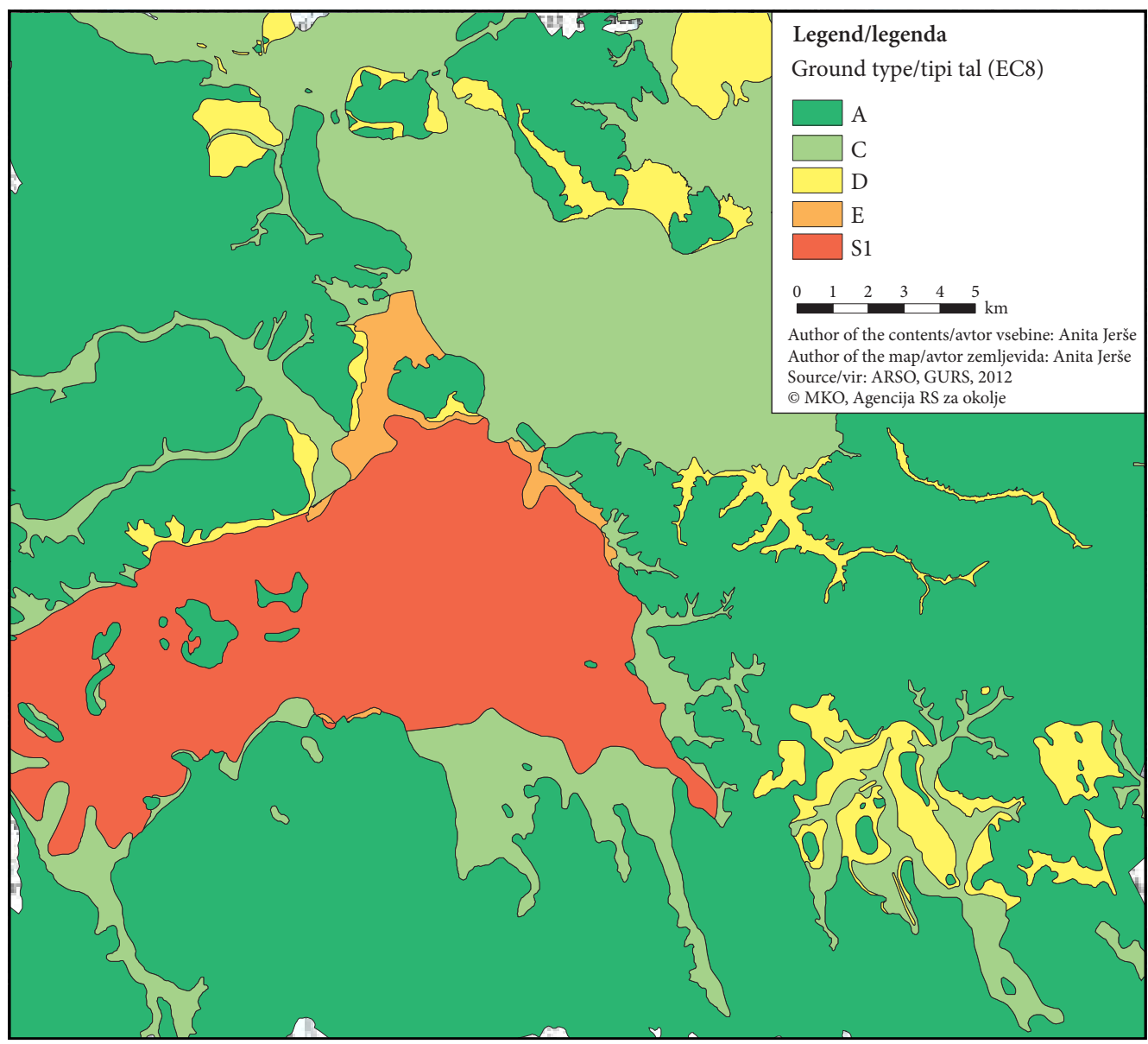

Figure 2: Map of EC8 ground types in the greater Ljubljana area.

We used ground classification based on EC8 according to the basic geological map (Zupančič et al. 2004), where the geological and lithological structure of the Ljubljana area was taken up by OGK 100, sheet Kranj (Grad and Ferjančič 1974), Ljubljana (Premru 1983), Postojna (Buser et al. 1967) and Ribnica (Buser 1969). Since the printed map OGK 100 is made on a relatively weak geodetic basis, the accuracy in the digital format is also poorer. Consequently, on the digital map they declared accuracy of the borders at $50 \mathrm{~m}$. Therefore, we have to consider that observers, who filled-in the macroseismic questionnaires and are located near the boundaries, may not be placed in the right class according to EC8.

The southwestern part of the study area (Ljubljana Moor) belongs to ground type $S_{1}$, most of the eastern and western part of the area belongs to ground type A, central part has been classified as ground type C, but there are also smaller areas which fall within ground type $\mathrm{D}$ and $\mathrm{E}$ (Figure 2). In the greater Ljubljana area there is no ground type $\mathrm{B}$ or $\mathrm{S}_{2}$.

\section{Macroseismic data collection and intensity assessment}

Effects of earthquakes on humans, objects, buildings and on nature are assessed by intensity, which is described by an intensity scale. In order to assess the intensity, the first step is to gather all the descriptive data available 


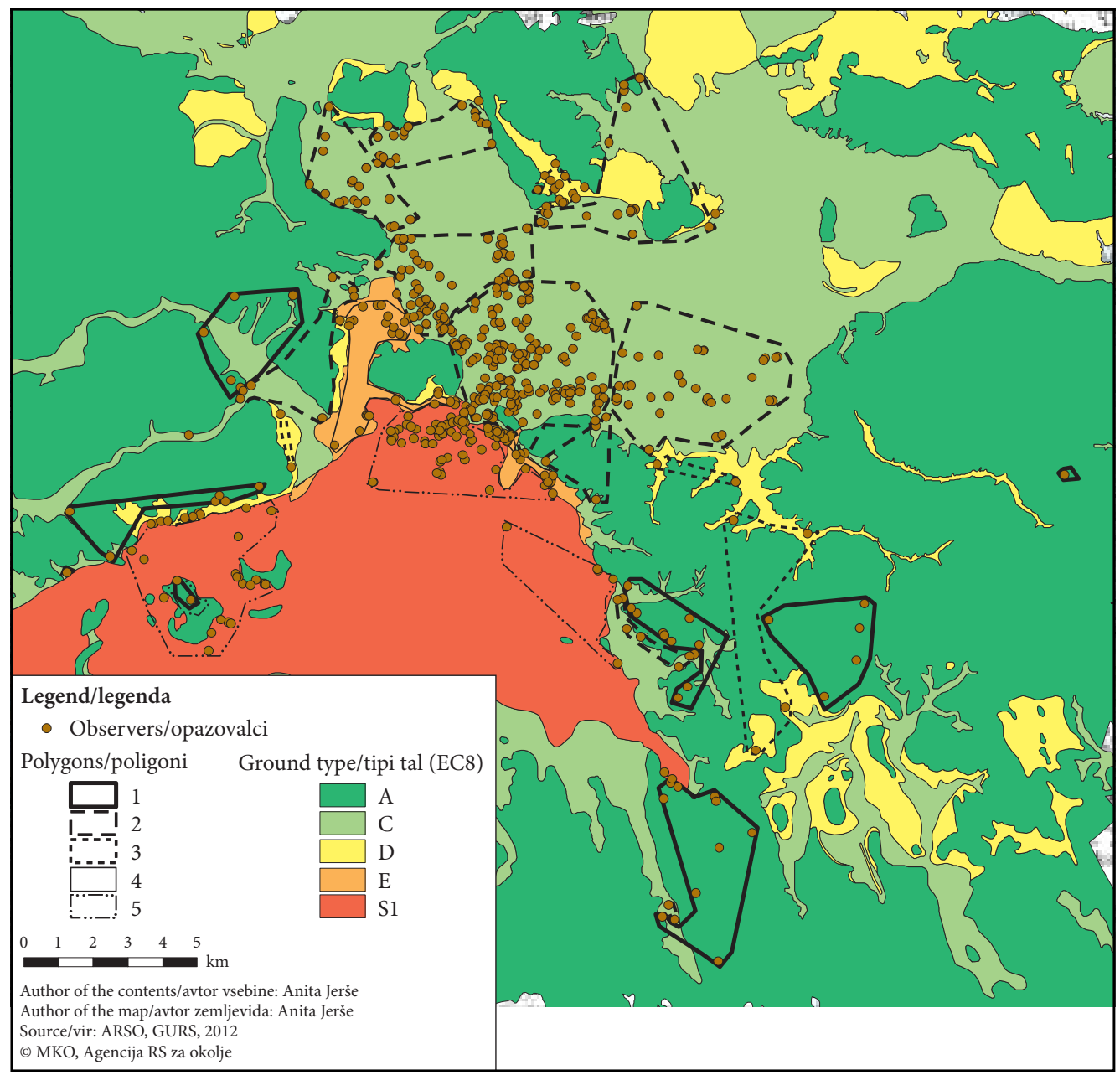

Figure 3: Map of polygons on homogeneous ground according to the EC8 classification for which we determined earthquake intensities. Points indicate the locations of the observers.

for a particular location. Then we sort the data by location and compare them with the lists of diagnostic elements and make a decision on which provides the best fit.

All macroseismic questionnaires are kept in the archives of Seismology and Geology Office. Macroseismic data include questionnaires, received by mail, via online web form and by e-mail.

We determined intensities for selected areas in Ljubljana according to ground classification based on EC8. Each determined intensity refers to small areas with a radius not exceeding $5 \mathrm{~km}$ and areas with homogeneous ground according to EC8, otherwise the range of shaking effects reported may be very large since geotechnical conditions of the ground vary. Consequently we divided the ground where observers reside into several polygons (Figure 3) and for each polygon we determined intensity of the earthquake. We have classified 4 polygons on the ground type $S_{1}, 2$ on ground $E, 6$ on ground $D, 10$ on ground $C$ and 8 polygons on ground type A. In estimating the intensity we followed the principles of EMS-98 (Grünthal 1998). 


\section{Methodology and data analysis}

For macroseismic data analysis we gathered 17 earthquakes (Table 1) which occurred between 1998 and 2005 and were strong enough for our purposes. From this group of 17 earthquakes, we then used 11 of them which best fulfilled the following requirements:

- that they occurred far enough from Ljubljana. In this case we can neglect the variations of epicentral distance between different parts of the city and thus we can see the differences in intensities due to the influence of geological substrates;

- that seismic waves are coming from similar directions. The influence of the geological structure on the propagation of earthquake waves is similar in this case;

- that they reached maximum intensity at least V EMS, and in the Ljubljana area an intensity of at least IV-V EMS;

- that there is sufficient macroseismic data available for them.

In the case of earthquakes which occurred in the vicinity of Brezovica (2002) and Cerkno (2005) there were several successive aftershocks, for which we have characterized the effects together, since there was insufficient data to allow precise assessment of the intensity for each shock separately.

Research was conducted for three separate groups of earthquakes. First, we focused on earthquakes (five of them) that best fulfilled the requirements. Their distance from Ljubljana is between 45 and $120 \mathrm{~km}$. Seismic waves of this group come to Ljubljana from the northwest. In the second group earthquakes do not fullfil the requirements so well (six of them). Their distance from Ljubljana is shorter, between 10 and $45 \mathrm{~km}$. Seismic waves have in these cases different arrival directions. The estimated intensities of earthquakes in this group are slightly lower than in the first group. The third group represents all eleven earthquakes. We analysed 1,296 questionnaires on seismic effects, filled-in by 616 observers. We dealt with the greater Ljubljana area, which extends in the south to Želimlje, in the north to Trzin, Dragomer in the west and in the east to the village Volavlje (Figure 3).

\section{Results and Discussion}

For each group we selected a comparative polygon with reference intensity and compared the intensity of other polygons with the reference one for each earthquake. The number of all estimated intensities is 224 and they are presented in Table 2.

In the table, beside intensities, there is also the number of questionnaires on which basis the intensity was estimated. Intensities, which are defined only on the basis of one questionnaire (marked red), were not used in the statistical analysis. In further research 160 intensities were used. In case when intensity is given as range for example IV-V EMS-98, we used the value of 4.5 for the calculation purpose.

We chose the polygon on ground type $\mathrm{C}$ as comparative, since it has mean values of geomechanical parameters in relation to other ground types. In the group of all eleven earthquakes, we chose the third one (C_3) as the comparative polygon, in the group of five earthquakes the second one (C_2), and in the group of other six earthquakes the fifth polygon (C_5). The selected polygon contains data for all earthquakes, does not contain any data that a single observer has not felt the earthquake, and has approximate mean value of intensity compared to other polygons on the ground C. We did not select polygon C_4 as comparative ground, because its values slightly deviate from the average.

For each polygon we calculated the deviation from the reference intensity for each earthquake separately and deviations of mean values from the reference intensity, which are: arithmetic mean, median, mode and modified median, where we have assumed that information "not felt « is the smallest. When calculating arithmetic mean we excluded data »not felt«.

First we made a statistical analysis of each individual polygon (Table 3), and then for grouped polygons according to ground type by EC8 (Table 4 ).

The results on the selection of five earthquakes showed that deviations from the reference intensity increased as the quality of the soil deteriorated (especially on ground type E). However, the results of ground type D deviate from others, since we would expect higher values than on ground $\mathrm{C}$ and not lower. This may be due to unrevealed geological or other factors. 


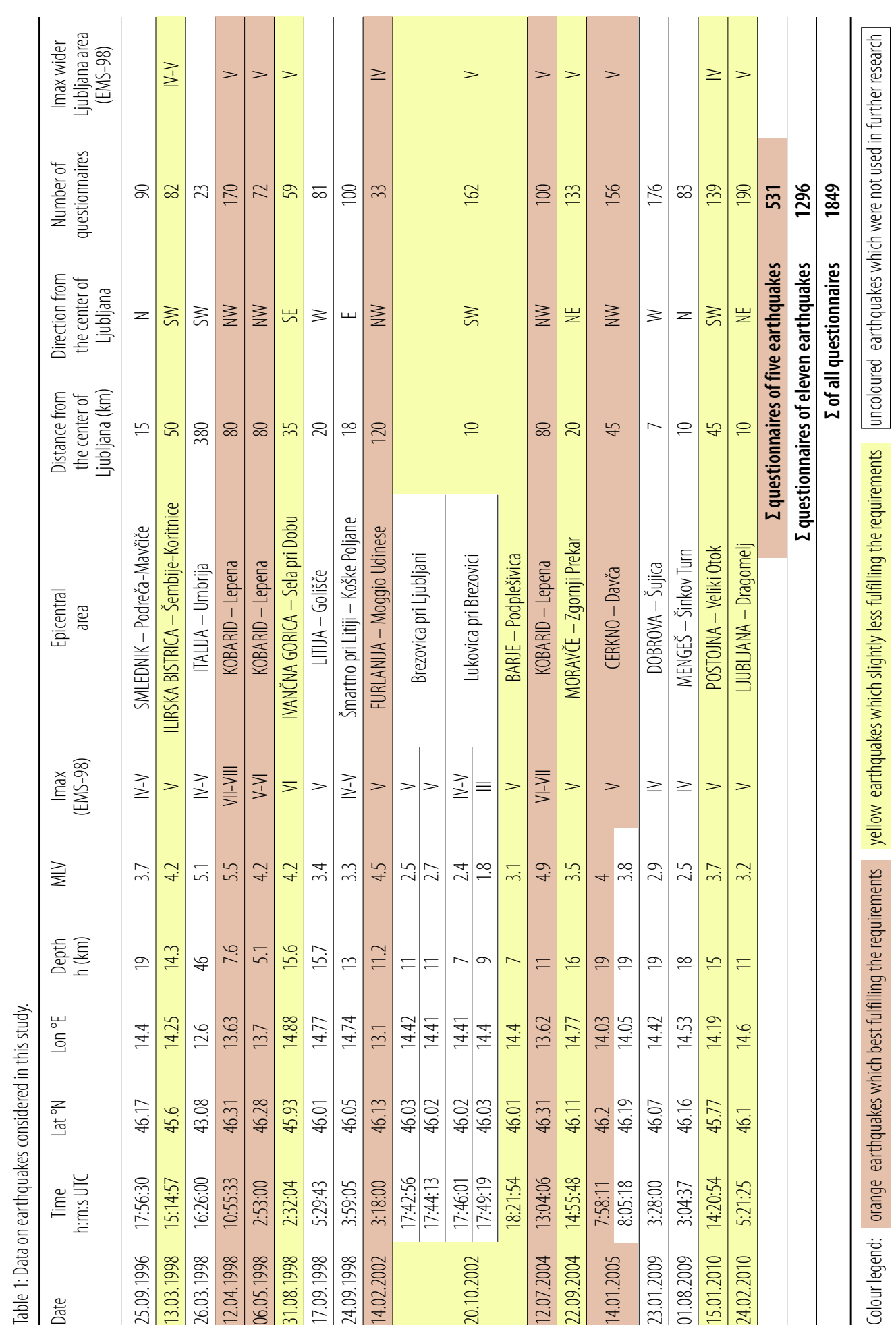




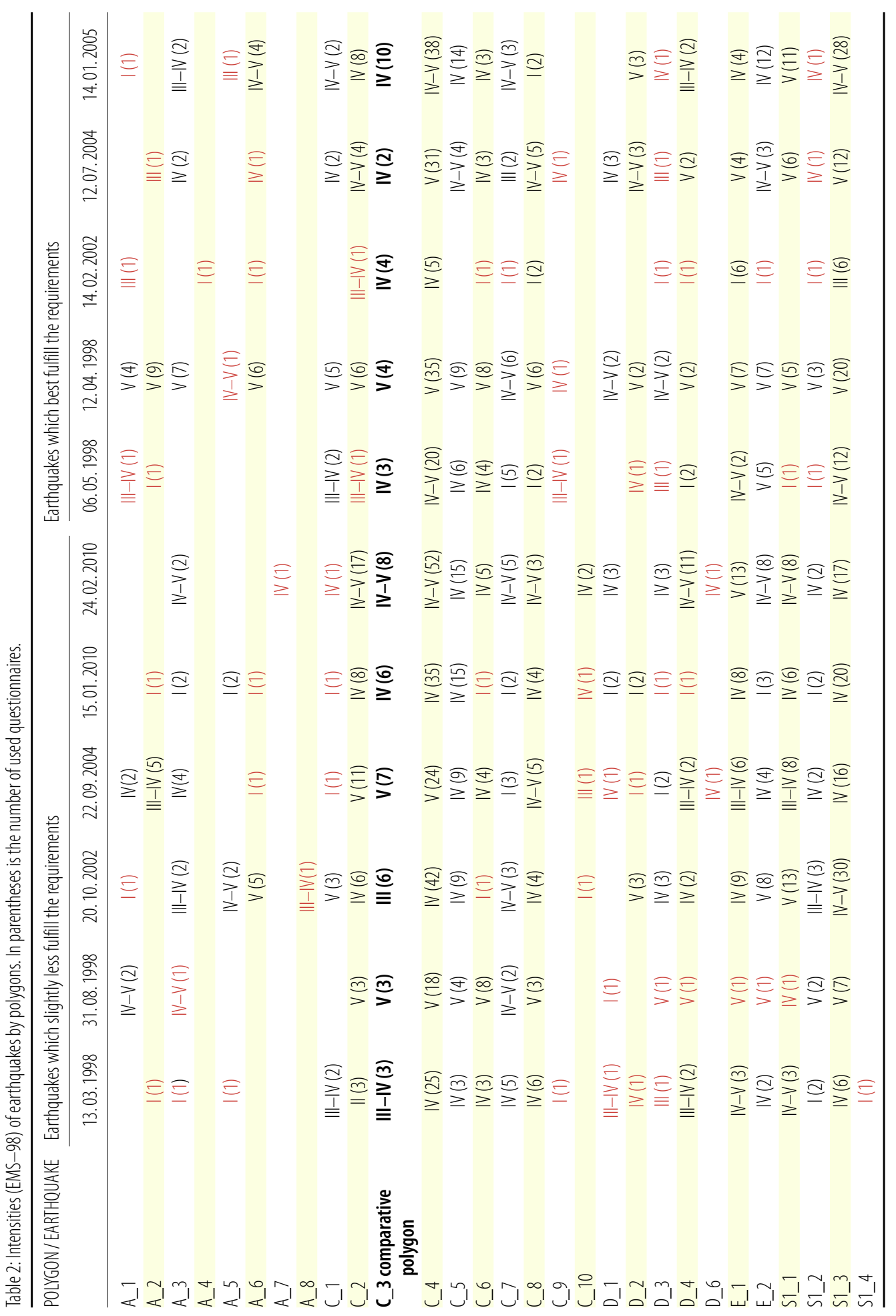




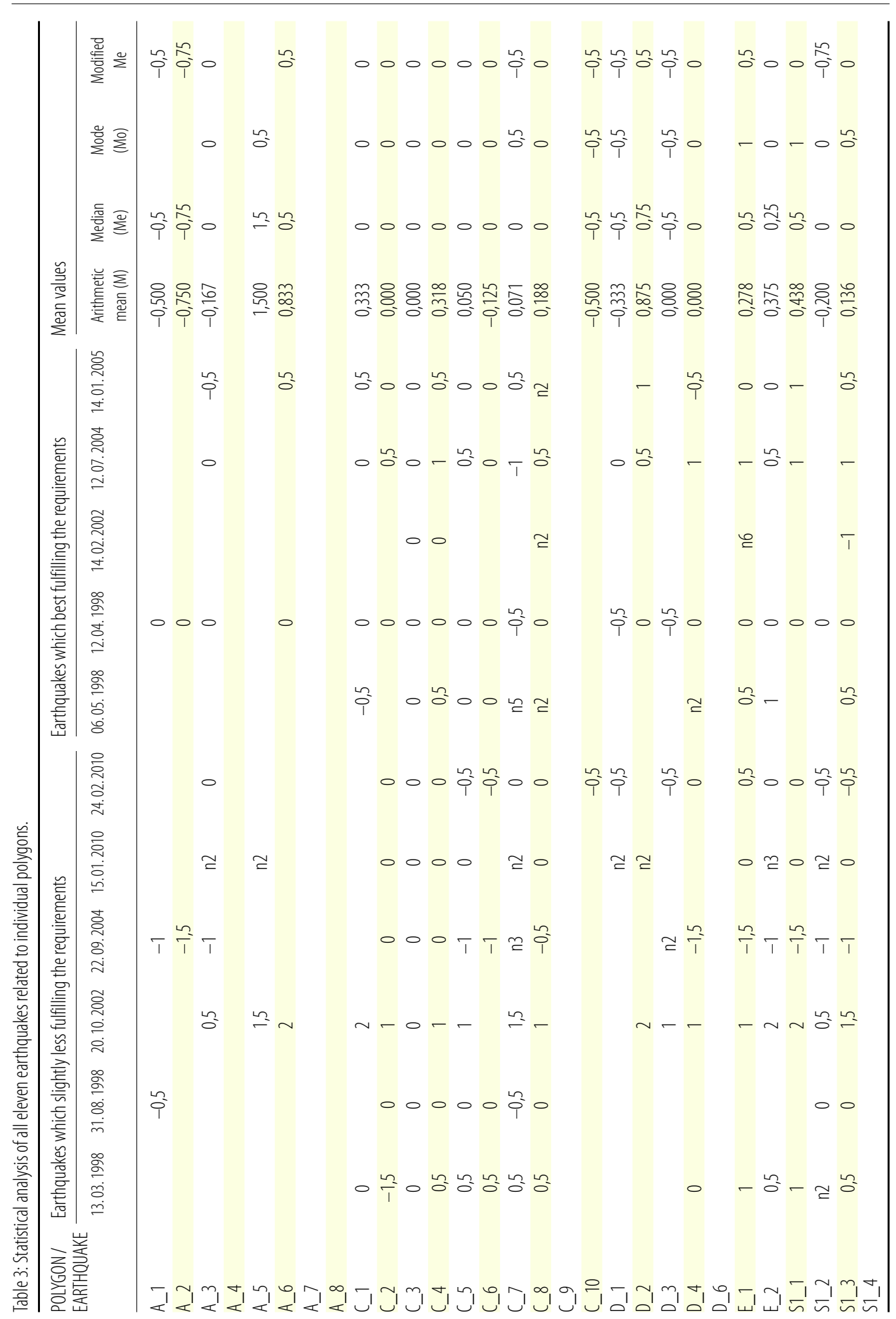


Table 4: Statistical analysis of earthquakes in accordance to EC8 classification for five earthquakes (top) and all eleven earthquakes together (bottom). Numbers next to ground type indicate how many intensities were considered in analysis.

\begin{tabular}{|c|c|c|c|c|}
\hline \multirow[t]{2}{*}{ Ground type (EC8) } & \multicolumn{4}{|c|}{ Mean values for five earthquakes } \\
\hline & Arithmetic mean (M) & Median (Me) & Mode (Mo) & Modified median \\
\hline$A(7)$ & $-0,071$ & 0 & 0 & 0 \\
\hline C(36) & 0,063 & 0 & 0 & 0 \\
\hline$D(10)$ & $-0,056$ & 0 & $-0,5$ & $-0,25$ \\
\hline$E(9)$ & 0,375 & 0 & 0 & 0 \\
\hline S1 (9) & 0,333 & 0,5 & 0 & 0,5 \\
\hline \multirow[t]{2}{*}{ Ground type (EC8) } & \multicolumn{4}{|c|}{ Mean values for all eleven earthquakes together } \\
\hline & Arithmetic mean (M) & Median (Me) & Mode (Mo) & Modifided median \\
\hline$A(17)$ & 0 & 0 & 0 & 0 \\
\hline C (77) & 0,092 & 0 & 0 & 0 \\
\hline$D(21)$ & 0,147 & 0 & $-0,5$ & 0 \\
\hline$E(19)$ & 0,324 & 0,5 & 0 & 0 \\
\hline S1 (26) & 0,167 & 0 & 0 & 0 \\
\hline
\end{tabular}

Table 5: The number of cases when the intensity of earthquakes is smaller, greater or equal to the reference intensity in accordance to EC8 classification. The results for the group of five earthquakes (top) and all eleven earthquakes together (bottom).

\begin{tabular}{|c|c|c|c|}
\hline \multirow[t]{2}{*}{ Ground type (EC8) } & \multicolumn{3}{|c|}{ Statistical analysis for five aearthquakes } \\
\hline & $|<|_{\text {ref }}$ & $I=I_{\text {ref }}$ & $1>\left.\right|_{\text {ref }}$ \\
\hline$A(7)$ & 2 & 4 & 1 \\
\hline C (36) & 9 & 12 & 10 \\
\hline$D(10)$ & 5 & 3 & 2 \\
\hline$E(9)$ & 1 & 5 & 3 \\
\hline S1 (9) & 1 & 3 & 5 \\
\hline \multirow[t]{2}{*}{ Ground type (EC8) } & \multicolumn{3}{|c|}{ Statistical analysis for all eleven earthquakes together } \\
\hline & $|<|_{\text {ref }}$ & $I=I_{\text {ref }}$ & $1>\left.\right|_{\text {ref }}$ \\
\hline$A(17)$ & 7 & 6 & 4 \\
\hline$C(77)$ & 17 & 30 & 19 \\
\hline$D(21)$ & 10 & 5 & 6 \\
\hline$E(19)$ & 4 & 6 & 9 \\
\hline Si (26) & 8 & 8 & 10 \\
\hline
\end{tabular}

Results on the total of eleven earthquakes show a similar rising trend of deviations from the reference intensity as with analysis on five earthquakes. On ground D we got higher arithmetic mean of then on the ground $\mathrm{C}$, but the mode is negative.

In Table 5 we present number of cases when intensity of earthquakes is smaller, greater or equal to the reference intensity on ground type $\mathrm{C}$ chosen as comparative ground. Blue indicates intensities that are prevailing on each ground.

For the group of five earthquakes the results showed an increase in the intensities of earthquakes as the quality of the soil deteriorated. Type A has more low intensities than high. The intensities of earthquakes on ground $\mathrm{C}$ are more equally distributed which was expected. Ground type E showed more high intensities than low and as well ground $S_{1}$. Ground type $S_{1}$ has also more high intensities than ground $E$, which is expected according to EC8. The only data to deviate is data for ground $\mathrm{D}$, which showed slightly lower intensities than the intensities on ground $\mathrm{C}$. We also noticed a significant data deviation within ground $\mathrm{D}$ 
intensities, suggesting a major influence of other factors. For the group of all eleven earthquakes we obtained similar results. Despite the fact that the other six earthquakes slightly less fulfil the requirements, we obtained similar results also for them.

We conducted also Wilcox rank-sum test (SPSS Inc. 1999), a nonparametric test to determine significant differences between mean values for independent samples. Test showed similar results as other tests, that the most distinguished ground from ground type $C$ is ground $S_{1}$ and the least is ground $D$.

\section{Conclusion}

Seismic wave amplification contributed to severe damage and loss of life in a number of earthquakes in the recent past. It is because of heavy damage to structures, caused by site effects on soft ground, that studies of the effects of the local ground increased so greatly. Since quantitative seismic ground-motion data are not always available for carrying out microseismic research, macroseismic data are important for analysis of earthquake effects.

The study covered the greater Ljubljana area, for which we estimated intensities by using 1,296 macroseismic questionnaires, which correspond to 11 different earthquakes. We determined intensities for areas with a radius not exceeding $5 \mathrm{~km}$ which were located on homogeneous ground according to EC8. We used ground classification based on EC8 derived from OGK (Zupančič et al. 2004), but in some lithological units difficulties in determining the ground types have emerged. This is mainly due to a lack of clarity in EC8 classification based on lithology and a lack of data on quantitative geomechanical properties. This applies especially for sediments in the Ljubljana Moor (ground type $S_{1}$ ). Ground where observers reside was divided into several polygons and for each polygon we determined seismic intensity.

Statistical analysis was done for three separate groups of earthquakes. For each group we selected the reference polygon on ground type $\mathrm{C}$, with which we compared the intensity of other polygons for the same earthquake. The results showed an increase in seismic intensities as the quality of the soil deteriorated. On ground type A there are more low intensities than high compared to the ground C. Intensities of earthquakes on ground $\mathrm{C}$ are more equally distributed. Ground type $\mathrm{E}$ and $\mathrm{S}_{1}$ showed more high intensities than low compared to the ground type $\mathrm{C}$. Ground $\mathrm{S}_{1}$ has also more high intensities than ground $\mathrm{E}$. Results on ground type D deviate from others, since according to EC8, we would expected higher values. This may be due to some unrevealed geological characteristics, like lateral distribution of soft ground, thickness of deposits, influence of topography or just because we have very limited macroseismic data for individual polygons within ground D. Therefore, it would be necessary to investigate also other properties of soft sediments in the future.

In general investigations based on intensity data in Slovenia are quite difficult to perform because there are not many strong earthquakes. Therefore, we have to use also lower intensity data, which are often not as indicative regarding the influence of local ground. The results of this study will contribute to a better assessment of seismic hazard in the greater Ljubljana area, because it is important that methodology of analysing macroseismic data sits side by side with other analyses of site effects.

ACKNOWLEDGEMENT: The authors are indebted to Ina Cecić for her help related to macroseismic data. Anita Jerše wishes to thank also Polona Zupančič for all the help using Geographic Information System (GIS).

\section{References}

Bradley, B. A. 2012: Ground motions observed in the Darfield and Christchurch earthquakes and the importance of local site response effects. New Zealand journal of geology and geophysics 55-3. DOI: http://dx.doi.org/10.1080/00288306.2012.674049

Buser, S. 1969: Osnovna geološka karta SFRJ 1:100.000, list Ribnica. Beograd.

Buser, S., Grad, K., Pleničar, M. 1967: Osnovna geološka karta SFRJ 1:100.000, list Postojna. Beograd.

Cecić, I. 2004: Metodologija prikupljanja i obrade makroseizmičkih podataka. Magistrsko delo, Fakulteta za znanost Univerze v Zagrebu. Zagreb. 
Cifelli, F., Donati, S., Funiciello, F., Tertulliani, A. 2000: High-density macroseismic survey in urban areas. Part 2: Results for the city of Rome, Italy. Bulletin of the Seismological society of America 90-2. DOI: http://dx.doi.org/10.1785/0119990097

Elder, D. McG., Mccahon, I. F., Yetton, M. D. 1991: The earthquake hazard in Christchurch: a detailed evaluation. Christchurch.

Giammarinaro, M. S., Tertulliani, A., Galli, G. 2005: Investigation of surface geology and intensity variability in the Palermo, Italy, urban area after the 6 September 2002 earthquake. Bulletin of the Seismological society of America 95-6. DOI: http://dx.doi.org/10.1785/0120040214

Gosar, A. 2007: Microtremor HVSR study for assessing site effects in the Bovec basin (NW Slovenia) related to 1998 Mw5.6 and 2004 Mw5.2 earthquakes. Engineering geology 91, 2-4. DOI: http://dx.doi.org/ 10.1016/j.enggeo.2007.01.008

Gosar, A. 2010: Site effects and soil-structure resonance study in the Kobarid basin (NW Slovenia) using microtremors. Natural hazards and earth system sciences 10-4. DOI: http://dx.doi.org/10.5194/ nhess-10-761-2010

Grad, K., Ferjančič, L. 1968: Osnovna geološka karta SFRJ $1: 100.000$, tolmač lista Kranj. Zvezni geološki zavod. Beograd.

Grünthal, G. 1998: European macroseismic scale 1998. Cahiers du Centre Européen de géodynamique et de séismologie 15.

Lapajne, J., Šket Motnikar, B., Zupančič, P. 2001: Karta potresne nevarnosti Slovenije - projektni pospešek tal in tolmač. Ljubljana.

Maugeri, M., Massimino, M. R., Grasso, S. 2013: The 2012 Emilia-Romagna earthquake (Italy): lesson and mitigation measurements. $18^{\text {th }}$ International conference on soil mechanics and geotechnical engineering. Paris.

Michetti, A. M., Esposito, E., Guerrieri, L., Porfido, S., Serva, L., Tatevossian, R., Vittori, E., Audemard, F., Azuma, T., Clague, J., Comerci, V., Gürpinar, A., McCalpin, J., Mohammadioun, B., Mörner, N. A., Ota, Y. and Roghozin, E. 2007: Environmental seismic intensity scale 2007 - ESI 2007, Memorie descrittive della Carta geologica d'Italia 74. Roma.

Pleničar, M. 1963: Osnovna geološka karta SFRJ 1:100.000, tolmač lista Postojna. Beograd.

Potresi - vprašalnik, 2014. Internet: http://www.arso.gov.si/potresi/vpra\%C5\%Alalnik/ (10.11.2014).

Premru, U. 1983: Osnovna geološka karta SFRJ $1: 100.000$, list Ljubljana. Beograd.

Premru, U. 1980: Osnovna geološka karta SFRJ 1 : 100.000, tolmač lista Ljubljana. Beograd.

Sbarra, P., De Rubies, V., Di Luzio, E., Mancini, M., Moscatelli, M., Stigliano, F., Tosi, P., Vallone, R. 2012: Macroseismic effects highlight site response in Rome and its geological signature. Natural hazards 62-2. DOI: http://dx.doi.org/10.1007/s11069-012-0085-9

SIST EN 1998-1, 2005: Evrokod 8 - Projektiranje potresnoodpornih konstrukcij 1, Splošna pravila, potresni vplivi in pravila za stavbe, slovenski standard. Ljubljana.

SIST EN 1998-1/A101, 2005: Evrokod 8 - Projektiranje potresnoodpornih konstrukcij 1, Splošna pravila, potresni vplivi in pravila za stavbe - Nacionalni dodatek. Ljubljana.

SPSS Inc. 1999: SPSS Base 9.0 applications guide.

Toshinawa, T., Taber, J. J., Berill, J. B. 1997: Distribution of ground-motion intensity inferred from questionnaire survey, earthquake recordings, and microtremor measurments - a case study in Christchurch, New Zealand, during the 1994 Arthurs pass earhquake. Bulletin of the Seismological society of America 87-2.

Zupančič, P., Šket Motnikar, B., Gosar, A., Prosen, T. 2004: Karta potresne mikrorajonizacije Mestne občine Ljubljana. Potresi v letu 2002. Ljubljana.

Zupančič, P. 2013: Mikrorajonizacija območij v Sloveniji z večjo potresno nevarnostjo. Potresi v letu 2012. Ljubljana. 


\section{Makroseizmične raziskave vplivov lokalne geološke zgradbe na intenzitete izbranih potresov na širšem območju Ljubljane}

DOI: http://dx.doi.org/10.3986/AGS.793

UDK: 550.34(497.451)

COBISS: 1.01

IZVLEČEK: Ljubljana leži na enem od treh potresno najbolj nevarnih območij v Sloveniji. Poleg tega mehkejši sedimenti v Ljubljanski kotlini močno vplivajo na potresno nihanje tal. Z makroseizmičnimi podatki smo raziskali vpliv geološke podlage na intenzitete nekaterih potresov na širšem območju Ljubljane. Določili smo intenzitete enajstih potresov na homogenih območjih, ki smo jih določili v skladu s klasifikacijo tal po evropskem standardu Evrokod 8 (EC8). Rezultati so pokazali sistematično povečevanje potresnih intenzitet, opredeljenih po Evropski potresni lestvici (EMS-98), s slabšanjem seizmogeoloških lastnosti tal. Rahlo odstopanje smo zaznali le na tleh vrste $\mathrm{D}$, na katerih imajo potresi nekoliko nižje intenzitete od pričakovanih. Vzrok se lahko skriva v ostalih geoloških in drugih dejavnikih ali zgolj v tem, da imamo za posamezna območja na tleh D zelo malo podatkov.

KLJUČNE BESEDE: Evropska potresna lestvica, intenziteta, makroseizmične raziskave, Evrokod 8, potresna mikrorajonizacija, Ljubljanska kotlina

\section{NASLOVI:}

\section{Anita Jerše}

Agencija RS za okolje

Urad za seizmologijo in geologijo

Dunajska 47, SI - 1000 Ljubljana, Slovenija

E-pošta: anita.jerse@gmail.com

\section{mag. Mladen Živčić}

Agencija RS za okolje

Urad za seizmologijo in geologijo

Dunajska 47, SI - 1000 Ljubljana, Slovenija

E-pošta: mladen.zivcic@gov.si

\section{dr. Andrej Gosar}

Agencija RS za okolje

Urad za seizmologijo in geologijo

Dunajska 47, SI - 1000 Ljubljana, Slovenija

in

Univerza v Ljubljani

Naravoslovnotehniška fakulteta

Aškerčeva cesta 12, SI - 1000, Ljubljana, Slovenija

E-pošta: andrej.gosar@gov.si 


\section{Uvod}

Potres je naravni pojav, ki ga ne moremo napovedati in nadzorovati, lahko pa ga dobro opišemo skozi analizo njegovih učinkov. Makroseizmični podatki podajalo sistematičen opis učinkov potresa na ljudi, predmete, zgradbe in naravo.

Amplituda nihanja tal je odvisna od žariščnih lastnosti potresa (magnituda, globina, oddaljenost, žariščni mehanizem), od vpliva regionalne geološke zgradbe na širjenje potresnega valovanja in od vpliva lokalne geološke zgradbe. Vpliv slednje imenujemo tudi vpliv lokalnih tal. Pri ocenjevanju potresne nevarnosti na mehkih tleh, pospešek nihanja tal na trdni skali v podlagi pomnožimo z ustreznim faktorjem tal.

Namen te raziskave je bil oceniti vpliv lokalne geološke zgradbe na intenzitete nekaterih potresov na širšem območju Ljubljane na podlagi klasifikacije tal po Evrokod 8 standardu (EC8) (SIST EN 1998-1, 2005; SIST EN 1998-1/A101, 2005). Za potrebe makroseizmičnih raziskav smo analizirali vprašalnike, ki jih hranimo v arhivu. Pri opredeljevanju intenzitete smo sledili načelom Evropske potresne lestvice (EMS-98) (Grünthal 1998). Intenzitete potresov smo določili za območja, katerih polmer ne presega $5 \mathrm{~km}$ in ki se nahajajo na homogenih tleh glede na EC8. Na podlagi geološke karte v merilu 1:100.000 in njenih tolmačev smo geološko podlago območja razdelili v pet razredov po EC8. Statistično analizo smo naredili za podatke treh ločenih skupin potresov. Pri vsaki skupini smo izbrali referenčno intenziteto primerjalnega poligona, s katero smo primerjali intenzitete drugih poligonov istega potresa.

\section{Dosedanje raziskave vpliva lokalne geološke zgradbe na učinke potresov}

Ojačitve potresnega valovanja v aluvialnih nanosih so že velikokrat prispevale k večji škodi in izgubi življenj, na primer v Christchurchu, 2011 (Bradley 2012) in v Emiliji-Romani 2012 (Maugeri s sod. 2013). Na območjih z zapleteno geološko sestavo se vpliv lokalnih tal lahko zelo spreminja (Toshinawa et. al. 1997). Po svetu je bilo narejenih že kar nekaj raziskav, s katerimi so na podlagi makroseizmičnih podatkov iskali povezavo med intenziteto in geološko podlago. Prve pomembnejše raziskave so bile narejene na Novi Zelandiji (Elder s sod. 1991, Toshinawa s sod. 1997). Tudi v Italiji je bilo opravljenih več raziskav o učinkih potresa npr. na območju Palerma (Giammarinaro s sod. 2005) in Rima (Cifelli s sod. 2000; Sbarra s sod. 2012). V Sloveniji smo velike razlike v poškodovanosti stavb opazovali v primeru potresov 1998 in $2004 \mathrm{v}$ Krnskem pogorju. Pretežno smo jih lahko pojasnili z resonančnimi učinki med tlemi in objekti (Gosar 2007; Gosar 2010).

Na podlagi novejših rezultatov so strokovnjaki predlagali (Sbarra s sod. 2012) uporabo makroseizmičnih rezidualov pri izdelavi kart potresne nevarnosti. Ugotovili so, da na intenziteto vpliva tudi spreminjanje tal z globino in debelina posameznih plasti.

\section{Geološke značilnosti in klasifikacija tal po EC8 na širšem območju Ljubljane}

Ljubljana, ki je eno od treh potresno najbolj nevarnih območij v Sloveniji (Lapajne s sod. 2001), leži v plitvem sedimentnem bazenu zapolnjenim s heterogenimi kvartarnimi nanosi (slika 1), ki imajo različne seizmogeološke lastnosti. Razlikujemo tri glavne dele: Ljubljansko polje, Ljubljansko barje in obrobno hribovje. Podlago bazena gradijo permski in karbonski skrilavi glinavci, peščenjaki in konglomerati ter mezozojske karbonatne kamnine, ki izdanjajo na robovih hribovja. Ljubljansko polje prekrivajo prodni nanosi reke Save, na Ljubljanskem barju pa sta prod in pesek prekrita z jezerski in barjanski sedimenti.

Slika 1: Geološka karta območja Ljubljane (Zupančičs sod. 2004).

Glej angleški del prispevka.

V EC8 je vpliv lokalnih tal na učinke potresa predpisan s koeficientom tal S (ang. soil factor), ki nam pove, koliko večje pospeške nihanja pričakujemo v primerjavi z referenčno trdno kamnino. EC8 določa 
sedem tipov tal, ki so opisani s stratigrafskim profilom in tremi kvantitativnimi parametri: hitrostjo strižnega valovanja v zgornjih $30 \mathrm{~m}\left(v_{\mathrm{s}, 30}\right)$, z rezultatom standardnega penetracijskega preizkusa $\left(\mathrm{N}_{\mathrm{spt}}\right)$ in strižno trdnostjo tal $\left(\mathrm{c}_{\mathrm{u}}\right)$. Za posebna tipa tal $\mathrm{S}_{1}$ in $\mathrm{S}_{2}$ koeficient tal ni podan in ga je treba določiti s posebnimi raziskavami.

Vpliv krajevne geološke sestave na potresno nihanje tal podaja karta potresne mikrorajonizacije. Na podlagi geološke karte (OGK 100) in njenih tolmačev smo razširili karto potresne mikrorajonizacije Mestne občine Ljubljana (Zupančič s sod. 2004) na širše območje Ljubljane (slika 2). Tla so razdeljena v pet razredov:

- A - koeficient 1,00 ,

- C - koeficient 1,15 ,

- D - koeficient 1,35 ,

- E - koeficient 1,70 ,

- $\mathrm{S}_{1}$ - koeficient 2,55.

Slika 2: Klasifikacija tal po EC8 na širšem območju Ljubljane.

Glej angleški del prispevka.

Uporabili smo klasifikacijo tal po EC8 na podlagi osnovne geološke karte (Zupančič s sod. 2004), kjer so geološko in litološko zgradbo območja Ljubljane povzeli po OGK 100, list Kranj (Grad in Ferjančič 1974), Ljubljana (Premru 1983), Postojna (Buser s sod. 1967) in Ribnica (Buser 1969). Ker je tiskana karta OGK 100 narejena na precej slabi geodetski podlagi, je tudi njena natančnost v digitalni obliki slabša. Na digitalni karti so zato privzeli natančnost mej $50 \mathrm{~m}$. Zato moramo upoštevati, da makroseizmični opazovalci, ki se nahajajo blizu meje, morda niso uvrščeni v pravi razred tal po EC8.

Jugozahodni del ozemlja (Ljubljansko barje) spada v tip tal $S_{1}$, večina vzhodnega in del zahodnega ozemlja spada v tla $A$, osrednji del v tla $C$, vmes pa so manjša območja, ki spadajo v tip tal D in E (slika 2). Na širšem območju Ljubljane ni ugotovljenih tal tipa B ali $\mathrm{S}_{2}$.

\section{Zbiranje makroseizmičnih podatkov in opredeljevanje intenzitete}

Oceno učinkov potresa na predmete, ljudi, zgradbe in naravo podaja intenziteta potresa, ki jo določimo s pomočjo intenzitetne lestvice. Prvi korak je pridobitev vseh opisnih informacij o učinkih potresa na določeni lokaciji. Podatke nato razvrstimo po naseljih ter jih primerjamo s seznamom diagnostičnih kriterijev ter določimo kateri opis intenzitetnih stopenj najbolj ustreza podatkom.

Makroseizmične vprašalnike hranimo v arhivu Urada za seizmologijo in geologijo. Podatki vključujejo vprašalnike, ki so jih opazovalci poslali po pošti, po elektronski pošti ali preko spletnega obrazca. Intenzitete smo določali za izbrana območja v Ljubljani, opredeljena s klasifikacijo tal po EC8 in ne po naseljih, kot je običajno. Vsaka ocenjena intenziteta se nanašala na območje, katerega polmer ne presega $5 \mathrm{~km}$, in ki se nahaja na homogenih tleh po EC8, saj je sicer razpon zabeleženih učinkov lahko zelo velik, glede na to da se geotehnične lastnosti tal spreminjajo. Posledično smo tla, kjer prebivajo opazovalci, razdelili na več poligonov (slika 3 ) in vsakemu poligonu določili intenziteto potresa. Določili smo 4 poligone na tleh tipa $\mathrm{S}_{1}$, 2 na tleh E, 6 na tleh D, 10 na tleh C in 8 poligonov na tleh tipa A. Pri opredeljevanju intenzitete smo sledili načelom Evropske potresne lestvice (EMS-98) (Grünthal 1998).

Slika 3: Poligoni homogenih tal glede na tip tal po EC8, za katere smo opredelili intenziteto potresov. Točke označujejo lokacije opazovalcev. Glej angleški del prispevka.

\section{Uporabljene metode in analiza podatkov}

Za analizo makroseizmičnih podatkov smo zbrali 17 potresov (preglednica 1), ki so se zgodili med letoma 1998 in 2005 ter so bili dovolj močni za naš namen. Iz te skupine smo nato uporabili 11 tistih, ki so čim bolje izpolnjevali naslednje pogoje:

- da so čim bolj oddaljeni od Ljubljane. V tem primeru lahko zanemarimo razlike v nadžariščni razdalji med različnimi deli mesta in tako vidimo razlike $\mathrm{v}$ intenzitetah zaradi vpliva geološke podlage; 
- da potresno valovanje prihaja iz podobne smeri. Vpliv geološke zgradbe na širjenje potresnega valovanja je v tem primeru podoben;

- da so dosegli največjo intenziteto najmanj V EMS, na območju Ljubljane pa najmanj IV-V EMS;

- da zanje obstoja zadostno število makroseizmičnih podatkov.

Pri potresih v okolici Brezovice (2002) in pri Cerknem (2005) je šlo za več zaporednih sunkov, katerih učinke smo opredeljevali skupaj, saj je bilo premalo podatkov, ki bi omogočili točno opredelitev intenzitete vsakega sunka posebej.

Raziskavo smo opravili za tri skupine potresov. Najprej smo se osredotočili na potrese (pet od njih), ki pogoje najbolje izpolnjujejo. Njihova oddaljenost od Ljubljane je med 45 in $120 \mathrm{~km}$. Potresno valovanje te skupine prihaja iz severozahodne smeri. Druga skupina potresov pogojev ne izpolnjuje tako dobro (šest od njih). Njihova oddaljenost od Ljubljane je manjša in sicer med 10 in $45 \mathrm{~km}$, potresno valovanje pa prihaja iz različnih smeri. Ocenjene intenzitete potresov te skupine so malo nižje od tistih v prvi skupini. Tretja skupina predstavlja vseh enajst potresov. Analizirali smo 1296 vprašalnikov o potresnih učinkih, ki jih je izpolnilo 616 opazovalcev. Obravnavali smo širše območje Ljubljane, ki se razteza na jugu do Želimelj, na severu do Trzina, na zahodu do Dragomera in na vzhodu do vasi Volavlje (slika 3).

\section{Rezultati in razprava}

Za vsako od treh skupin potresov smo izbrali primerjalni poligon, katerega intenziteta je bila referenčna. $\mathrm{Z}$ njo smo primerjali intenzitete drugih poligonov za vsak potres (preglednica 3). Število vseh ocenjenih intenzitet znaša 224 in so podane v preglednici 2.

$\mathrm{V}$ preglednici je poleg intenzitete $\mathrm{v}$ oklepaju podano še število vprašalnikov na podlagi katerih je bila intenziteta opredeljena. Intenzitet, ki so določene le na podlagi enega vprašalnika (označeno rdeče), nismo uporabili v statistični analizi. V nadaljnji raziskavi smo uporabili 160 intenzitet. Pri razponu intenzitet, npr. IV-V EMS, je bila v izračunih uporabljena vrednost 4,5.

Za primerjalnega smo izbrali poligon na tleh tipa $\mathrm{C}$, saj imajo tla $\mathrm{C}$ srednje vrednosti geomehanskih parametrov glede na ostale tipe tal. V skupini vseh enajstih potresov smo izbrali tretji (C_3), v skupini petih potresov drugega (C_2) in v skupini ostalih šest potresov peti poligon (C_5). Izbran poligon vsebuje podatke za vse potrese, ne vsebuje podatka, da opazovalec potresa ni čutil, in ima približne srednje vrednosti intenzitet $\mathrm{v}$ primerjavi $\mathrm{z}$ ostalimi poligoni na tleh C. Poligona C_4 nismo izbrali za primerjalnega, ker njegove vrednosti nekoliko odstopajo od povprečnih.

Za vsak poligon smo izračunali odstopanje od referenčne intenzitete za vsak potres posebej ter več srednjih vrednosti odstopanj od referenčne intenzitete, in sicer: aritmetično sredino, mediano, modus in modificirano mediano, pri kateri smo predpostavili, da je podatek »ni čutil« najmanjši. Pri izračunu aritmetične sredine pa podatka nismo upoštevali, če opazovalci potresa niso čutili.

Najprej smo opravili statistično analizo vsakega posameznega poligona (preglednica 3) in nato še za združene poligone glede na tip tal po EC8 (preglednica 4).

Rezultati na podlagi petih potresov kažejo, da odstopanja od referenčne intenzitete naraščajo s slabšanjem lastnosti tal (predvsem na tleh tipa E). Vendar pa rezultati tipa tal D odstopajo od ostalih, saj bi glede na koeficient tal po EC8 pričakovali višje vrednosti od tistih na tleh C in ne manjše. Verjetno tičijo vzroki v neodkritih geoloških in ostalih dejavnikih.

Rezultati na podlagi vseh enajstih potresov kažejo podoben trend naraščanja vrednosti odstopanj od referenčne intenzitete kot pri rezultatih analize petih potresov. Na tleh D dobimo višjo aritmetično sredino od tiste na tleh $\mathrm{C}$, nasprotno pa je modus negativen.

$\mathrm{V}$ preglednici 5 podajamo, kolikokrat je bila intenziteta manjša, večja ali enaka referenčni intenziteti na tleh C, ki so bila privzeta za primerjalna tla. Modra barva označuje intenzitete, ki prevladujejo na posameznih tleh.

V skupini petih potresov je vidno poviševanje intenzitet s slabšanjem tal. Na tipu tal A imamo opredeljenih več nižjih intenzitet kot višjih. Tla $\mathrm{C}$ imajo precej enakomerno razporejene intenzitete, kar je pričakovano, glede na to, da smo ta tla izbrali za primerjalna. Tla $\mathrm{E}$ imajo več višjih intenzitet kot nižjih in prav tako tudi tla $S_{1}$. Tla $S_{1}$ imajo tudi več višjih intenzitet kot tla E, kar je pričakovano po EC8. Edini podatki, ki odstopajo, so tisti za tla $\mathrm{D}$, saj so intenzitete na teh tleh nekoliko nižje od intenzitet na tleh C. Opazili pa smo veliko odstopanje intenzitet znotraj tal $\mathrm{D}$, kar nakazuje velik vpliv drugih dejavnikov. V preglednici 


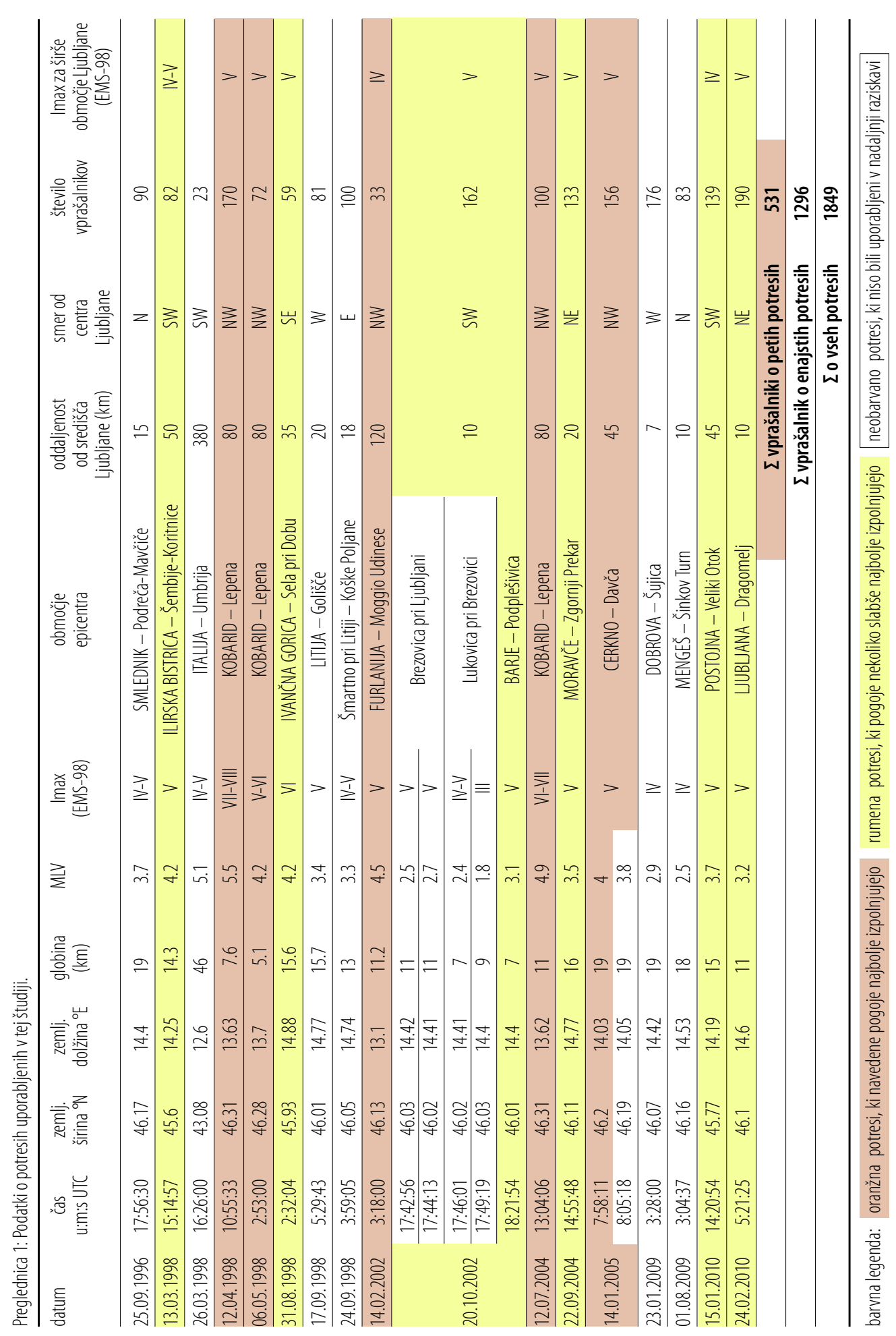




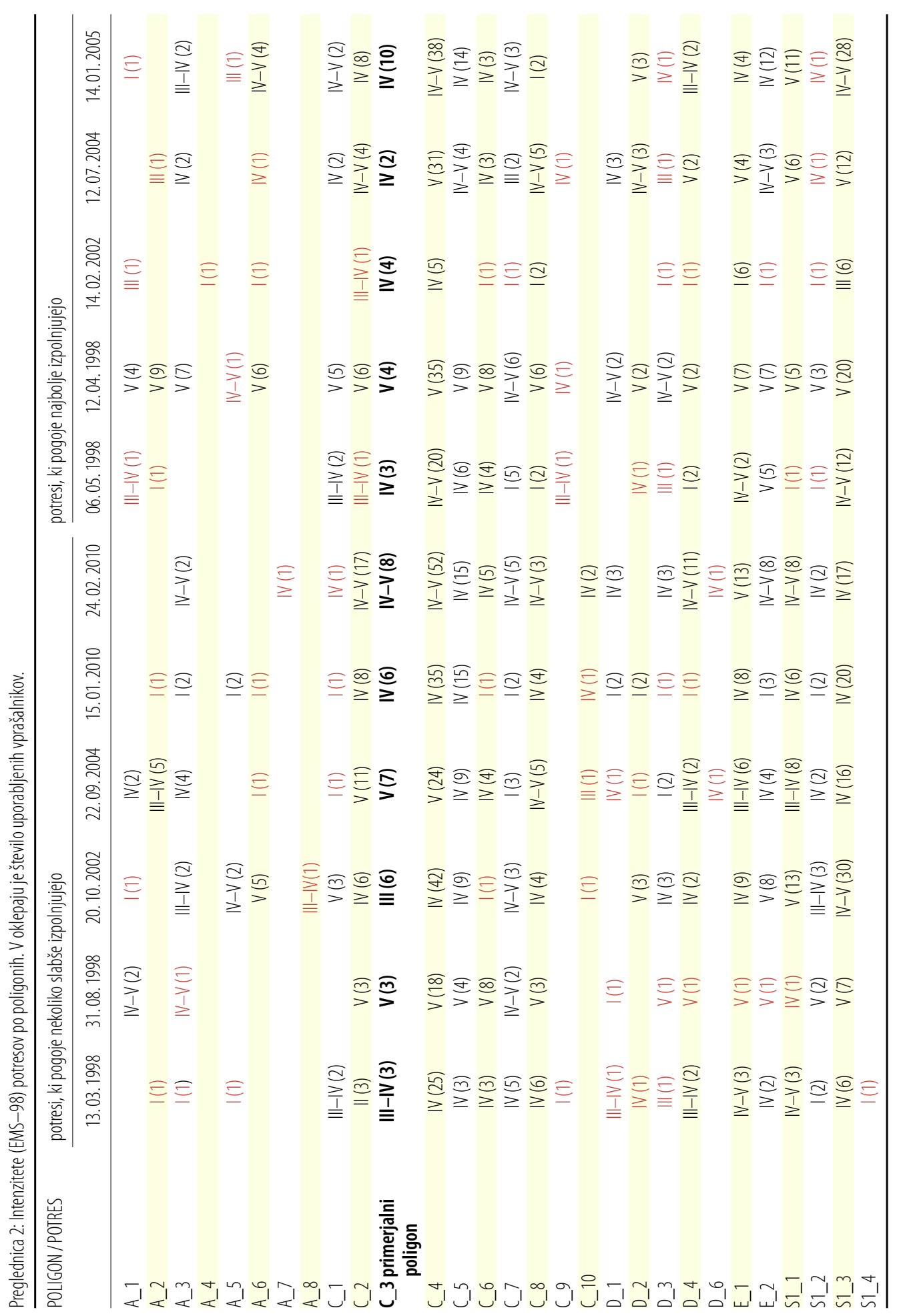




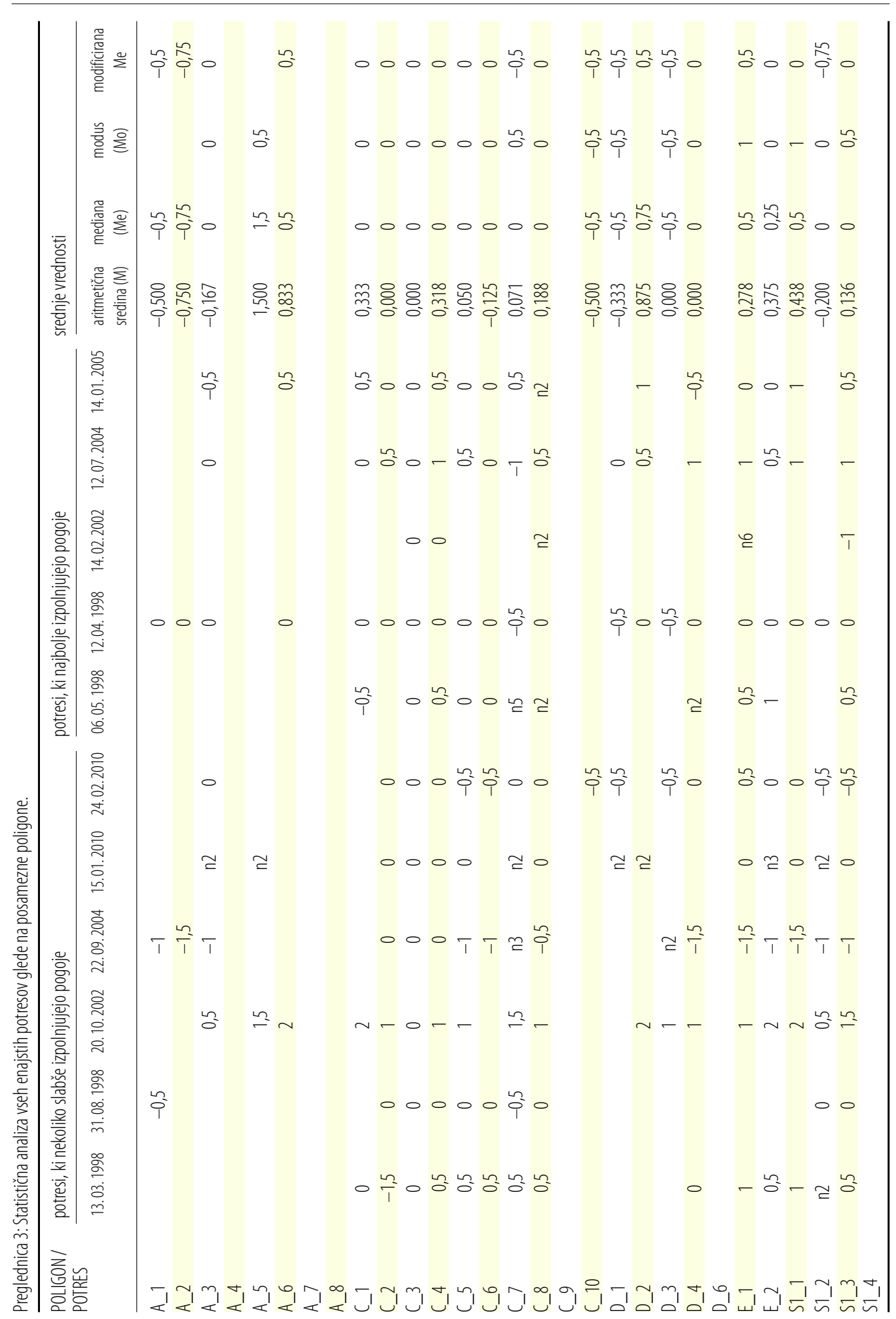


Preglednica 4: Statistična analiza potresov glede na tip tal po EC8 za pet potresov (levo) in vseh enajst potresov skupaj (desno). Številke poleg tipa tal označujejo koliko intenzitet je bilo uporabljenih v analizi.

\begin{tabular}{|c|c|c|c|c|}
\hline \multirow[t]{2}{*}{ tip tal (EC8) } & \multicolumn{4}{|c|}{ srednje vrednosti za pet potresov } \\
\hline & aritmetična sredina (M) & mediana (Me) & modus (Mo) & modificirana Me \\
\hline$A(7)$ & $-0,071$ & 0 & 0 & 0 \\
\hline$C(36)$ & 0,063 & 0 & 0 & 0 \\
\hline$D(10)$ & $-0,056$ & 0 & $-0,5$ & $-0,25$ \\
\hline$E(9)$ & 0,375 & 0 & 0 & 0 \\
\hline S1 (9) & 0,333 & 0,5 & 0 & 0,5 \\
\hline
\end{tabular}

\begin{tabular}{lcccc} 
tip tal (EC8) & \multicolumn{3}{c}{ srednje vrednosti za vseh enajst potresov } & \\
\cline { 2 - 5 } & aritmetična sredina (M) & mediana (Me) & modus (Mo) & modificirana Me \\
\hline A (17) & 0 & 0 & 0 & 0 \\
C(77) & 0,092 & 0 & 0 & 0 \\
D (21) & 0,147 & 0 & 0 & 0 \\
E (19) & 0,324 & 0,5 & 0 & 0 \\
S1 (26) & 0,167 & 0 & 0 & 0 \\
\hline
\end{tabular}

Preglednica 5: Število primerov, ko je intenziteta manjša, enaka ali večja referenčni intenziteti primerjalnih tal po EC8. Rezultati za skupino petih potresov (levo) in vseh enajstih potresov skupaj (desno).

\begin{tabular}{|c|c|c|c|}
\hline \multirow[t]{2}{*}{ tip tal (EC8) } & \multicolumn{3}{|c|}{ statistična analiza za pet potresov } \\
\hline & $1<\left.\right|_{\text {ref }}$ & $I=\left.\right|_{\text {ref }}$ & $1>\left.\right|_{\text {ref }}$ \\
\hline$A(7)$ & 2 & 4 & 1 \\
\hline$C(36)$ & 9 & 12 & 10 \\
\hline$D(10)$ & 5 & 3 & 2 \\
\hline$E(9)$ & 1 & 5 & 3 \\
\hline S1 (9) & 1 & 3 & 5 \\
\hline \multirow[t]{2}{*}{ tip tal (EC8) } & \multicolumn{3}{|c|}{ statistična analiza za vseh enajst potresov } \\
\hline & $1<\left.\right|_{\text {ref }}$ & $I=\left.\right|_{\text {ref }}$ & $1>\left.\right|_{\text {ref }}$ \\
\hline$A(17)$ & 7 & 6 & 4 \\
\hline$C(77)$ & 17 & 30 & 19 \\
\hline$D(21)$ & 10 & 5 & 6 \\
\hline$E(19)$ & 4 & 6 & 9 \\
\hline$S 1(26)$ & 8 & 8 & 10 \\
\hline
\end{tabular}

intenzitet vseh enajstih potresov smo dobili podobne rezultate. Kljub temu, da ostalih šest potresov nekoliko slabše izpolnjuje pogoje, smo tudi pri njih dobili podobne rezultate.

Opravili smo tudi Wilcoxov rank-sum test (SPSS Inc. 1999), to je neparametričen test, da bi določili značilne razlike med srednjimi vrednostmi neodvisnih vzorcev. Pokazal je podobne rezultate kot drugi testi in sicer, da se od tal C najbolj razlikujejo tla $S_{1}$ in najmanj tla D.

\section{Sklep}

Ojačitve potresnega valovanja so v preteklosti pogosto prispevale k večji škodi in izgubi življenj ob potresih. Prav zaradi težkih poškodb objektov, povzročenih z lokalnimi učinki, so se študije vplivov mehkih 
sedimentov zelo povečale. Ker kvantitativni podatki gibanja tal niso vedno na voljo za izvedbo mikroseizmičnih raziskav, je pomembna analiza makroseizmičnih podatkov o učinkih potresa.

Raziskave so zajele širše območje Ljubljane, za katerega smo opredelili intenzitete z uporabo 1296 makroseizmičnih vprašalnikov, ki so se nanašali na 11 različnih potresov. Intenzitete smo določali za območja katerih polmer ni presegel $5 \mathrm{~km}$ in ki ležijo na homogenih tleh po EC8. Tla smo klasificirali po EC8 na podlagi OGK (Zupančič s sod. 2004), vendar se je pri nekaterih litoloških enotah pojavila dilema pri določanju tipa tal. Vzrok je predvsem v nedorečenosti pri klasificiranju tal po EC8 glede na opis litološke sestave in pomanjkanju kvantitativnih podatkov o geomehanskih lastnostih. To velja predvsem za sedimente Ljubljanskega barja (tip tal $\mathrm{S}_{1}$ ). Območje smo nato znotraj istega tipa tal razdelili na več poligonov in vsakemu poligonu določili intenziteto potresa.

Statistične analize smo opravili na treh različnih skupinah potresov. Za vsako skupino smo izbrali referenčni poligon na tipu tal C. Rezultati so pokazali povišanje intenzitete potresov na slabših tleh. Na tipu tal A je bilo opredeljenih več nižjih intenzitet kot višjih v primerjavi s tlemi C. Intenzitete potresov na tleh C so enakomerno razporejene. Tla $\mathrm{E}$ in S1 imajo več višjih intenzitet kot nižjih v primerjavi s tlemi tipa C. Tla S1 pa imajo tudi več višjih intenzitet kot tla E. Na tipu tal D se pojavi odstopanje rezultatov, saj bi po EC8 pričakovali višje vrednosti. Morda tičijo vzroki v ostalih neodkritih geoloških dejavnikih, kot so lateralna razširjenost mehkih zemljin, debelina nanosov, vpliv topografije ali pa zgolj v tem, da imamo za posamezne poligone na tleh D zelo malo podatkov. V prihodnje bi bilo torej dobro raziskati tudi druge lastnosti mehkih sedimentov.

Raziskave na podlagi podatkov o intenzitetah je v Sloveniji dokaj težko opravljati, saj ni veliko močnih potresov. Zato se moramo zadovoljiti s podatki o nižjih intenzitetah, ki pa pogosto niso tako indikativni glede vpliva lokalnih tal. Rezultati te študije prispevajo k boljši oceni potresne nevarnosti na širšem območju Ljubljane, saj je pomembno, da metodologijo analize makroseizmičnih podatkov postavimo ob bok drugim metodam analize lokalnih učinkov potresov.

ZAHVALA: Avtorji se zahvaljujejo Ini Cecić za pomoč v zvezi z makroseizmičnimi podatki. Anita Jerše se zahvaljuje tudi Poloni Zupančič za vso pomoč pri uporabi geografskega informacijskega sistema (GIS).

\section{Literatura}

Glej angleški del prispevka. 